DOI: https://doi.org/10.32838/2523-4803/69-6-26

удк 338.58

\title{
Клименко I.C.
}

кандидат технічних наук, доцент, доцент кафедри економіки,

Національний транспортний університет

Кривошеєва С.В.

старший викладач кафедри економіки,

Національний транспортний університет

Кривенко О.К.

старший викладач кафедри економіки,

Національний транспортний університет

Klymenko Iryna, Krivosheeva Svetlana, Kryvenko Olena

National Transport University

\section{ПРОБЛЕМИ ТА ПЕРСПЕКТИВИ РОЗВИТКУ РИНКУ ПАСАЖИРСЬКИХ АВТОМОБІЛЬНИХ ПЕРЕВЕЗЕНЬ В УКРАЇНІ}

\begin{abstract}
У статті розглянуто ринок пасажирських перевезень в Украйні. Визначені економічні, правові, техніко-технологічні і соціальні проблеми розвитку автомобільного транспорту. Сформовані проблемі позиції щзодо якості обслуговування пасажирів. Найбільша частка перевезень пасажирів припадає на наземний транспорт, ие більше ніж 99\%, на авіаційний транспорт припадає більше 1\%, водним транспортом здійснюється найменша кількість пасажирських перевезень. Пасажирооборот залізничного та автомобільного (автобуси) транспорту протягом п'яти років (2014-2018 рр.) зазнав несуттєвих змін. Хоча показники 2018 року значно нижчі від даних 2014 року, проте порівняно з попереднім роком є позитивна динаміка. Зазначено перелік урядових заходів для підвищення ефективності функиіонування транспортного комплексу Украӥни.

Ключові слова: пасажирські перевезення, транспортна галузь, автомобільний транспорт, автомобілізація, пасажирооборот.
\end{abstract}

Постановка проблеми. Однією 3 ключових стратегічно важливих ланок економічної системи держави $€$ транспорт. Ефективна робота транспортної галузі суттєво впливає на підвищення добробуту населення. Автомобільний транспорт $є$ могутнім сектором економіки, що обслуговує практично всі галузі господарства і всі верстви населення, сприяє розвитку транспортно-економічних зв'язків і покращенню якості життя населення.

Для забезпечення ефективного управління пасажирськими перевезеннями виникає необхідність у розробленні цілісної системи заходів. Для вирішення цієї проблеми застосовують інноваційні розробки та впроваджують нові техніки та технології.

Аналіз останніх досліджень і публікацій. У працях таких учених, як Л.Л. Афанасьєв, А.І. Воркут, М.Ф. Дмитриченко, В.К. Доля, О.С. Ігнатенко, О.Я. Коцюк, П.Р. Левковець, Л.Б. Миротін, Е.В. Мун, В.П. Поліщук, О.Л. Петрашевський, Р.А. Хабутдінов, М.С. Фішельсон та інші розглянута методологія управління транспортними процесами і системами міжнародних перевезень.

Відомі вчені І.Я. Аксьонов, І.М. Аксьонов, М.В. Андреєва, О.О. Бакаєв, В.Я. Бєлозьоров, М.Н. Бідняк, А.І. Воркут, В.Г. Галабурда, Ю.М. Гончаров, В.Т. Єлагін, В.М. Загорулько, В.Г. Коба, М.І. Котлубай, Ю.Ф. Кулаєв,
Б.С. Марчук, В.В. Мова, А.В. Перепелюк, С.М. Сич, Ю.М. Цвєтов, В.І. Щелкунов, Л.А. Ященко та інші досліджували методологічні основи та вивчали практичні аспекти розвитку транспортного сектору. Отже, стан та перспективи розвитку ринку автомобільних перевезень потребують окремої уваги та додаткових досліджень.

Формування цілей статті. Метою статті $є$ аналіз сучасного стану ринку автомобільних пасажирських перевезень в Україні для визначення шляхів удосконалення транспортного обслуговування пасажирських перевезень автомобільним транспортом.

Виклад основного матеріалу. Для ефективного здійснення пасажирських перевезень необхідно дотримуватися певних технічних вимог, впроваджувати політику енергозбереження та раціонального використання наявного складу автомобілів [1, с. 56].

Автомобілізація, окрім позитивних загальновідомих аспектів, має і негативні: соціальні й економічні наслідки дорожньо-транспортних пригод, екологічні наслідки шкідливих викидів, незадовільний стан автомобільних доріг.

Економічні, правові, техніко-технологічні і соціальні проблеми розвитку автомобільного транспорту наведені в табл. 1 . 
Основні проблеми розвитку автомобільного транспорту

\begin{tabular}{|c|c|}
\hline $\begin{array}{c}\text { Категорія } \\
\text { проблем }\end{array}$ & Суть проблеми \\
\hline \multirow{6}{*}{ Економічні } & $\begin{array}{l}\text { невідповідність тарифів на пасажирському автомобільному транспорті витратам автоперевізників на збитко- } \\
\text { вих маршрутах; }\end{array}$ \\
\hline & $\begin{array}{l}\text { відсутність чіткого механізму обліку та компенсації збитків автоперевізників від пільгових перевезень паса- } \\
\text { жирів; }\end{array}$ \\
\hline & $\begin{array}{l}\text { економічна невигідність обслуговування автомобільним транспортом загального користування населення } \\
\text { сільських населених пунктів } 3 \text { малою кількістю жителів; }\end{array}$ \\
\hline & $\begin{array}{l}\text { обмеженість державного фінансування робіт з ремонту та експлуатаційного утримання мережі автомобільних } \\
\text { доріг загального користування; }\end{array}$ \\
\hline & невідповідність структури автобусного парку попиту на його послуги; \\
\hline & зменшення кількості базових автопідприємств, що працюють на ринку пасажирських перевезень; \\
\hline \multirow{3}{*}{ Правові } & недосконалість контролю за режимом роботи й відпочинку водіїв автотранспортних засобів; \\
\hline & збитки держави від роботи автоперевізників, які не мають відповідних дозвільних документів; \\
\hline & недостатнє забезпечення пріоритетності умов руху громадського пасажирського транспорту; \\
\hline \multirow{4}{*}{$\begin{array}{l}\text { Техніко- } \\
\text { технологічні }\end{array}$} & знос рухомого складу та відсутність достатніх можливостей для його оновлення; \\
\hline & $\begin{array}{l}\text { недостатній інноваційний розвиток, недостатнє стимулювання державою інноваційних процесів і науково- } \\
\text { технічних розробок у галузі автотранспортних перевезень; }\end{array}$ \\
\hline & недостатня кількість паркінгів для відстою транспорту та відпочинку водіїв; \\
\hline & $\begin{array}{l}\text { неефективне використання рухомого складу перевізниками (продуктивність рухомого складу на окремих } \\
\text { ділянках мінімальна); }\end{array}$ \\
\hline \multirow{3}{*}{ Соціальні } & низький рівень комфорту в громадському пасажирському транспорті; \\
\hline & зростання використання власного автотранспорту; \\
\hline & низька якість перевезень загалом; \\
\hline
\end{tabular}

Не до кінця вирішеними залишаються такі позиції щодо якості обслуговування пасажирів:

- не повністю розроблені важелі економічного впливу на наявних перевізників у випадках порушення стандартів якості обслуговування пасажирів на маршрутах;

- відсутній механізм справедливої конкуренції між перевізниками, який може створити умови для рівної конкурентної боротьби;

- відсутність статистичних матеріалів щодо моніторингу якості обслуговування пасажирів;

- відсутність збору кількісних показників, що оцінюють наявність пасажирів в салоні транспортної одиниці, і тих, що чекають на зупинці.

Негативний вплив на розвиток транспортної галузі чинить ситуація збитковості галузі та рівень зносу рухомого складу, який досягає 80-100\%, обмеженість обсягів кредитів міжнародних фінансових організацій, низьке фінансування утримання автомобільних доріг, дорогі кредитні ресурси українських банків та відсутність дієвих концесійних механізмів. [2, с. 37]. Окрему проблему становить наявність значної кількості «нелегальних перевізників», що працюють на пасажирських маршрутах без відповідного дозволу органів влади та не звітують перед державними фіскальними органами. «Нелегальні перевізники» є загрозою безпечного руху автомобільного транспорту.

Відомо, що конкуренція часто приводить до підвищення рівня якості обслуговування пасажирів. Соціально-економічна значущість автомобільного транспорту є незаперечною. Тому потреба в якісному транспортному обслуговуванні населення постійно зростає.
Найбільша частка перевезень пасажирів припадає на наземний транспорт, це більше ніж 99\%, на авіаційний транспорт припадає більше $1 \%$, водним транспортом здійснюється найменше пасажирських перевезень. Варто зазначити, що частка перевезень авіаційним транспортом зросла за останні два аналізовані роки на 0,049\% та на 0,050\% відповідно. Динамічні зміни за п'ятирічний аналізований період розглянуто на рис. 1 [3, 20.11.2019]

У табл. 2 наведено кількість перевезених пасажирів різними видами транспорту загального користування за період 2014-2018 років.

Аналіз наведених даних показує, що основний обсяг перевезень пасажирів здійснюється за 2018 р. автомобільним транспортом (автобусами), трамвайним, тролейбусним, метрополітенівським та залізничним транспортом їхня частка від загального обсягу перевезень становить 43,43\%, 14,54\%, 22,76\%, 15,46\% та 3,55\% відповідно.

Індекси обсягу перевезення пасажирів показують тенденцію зростання за 2017-2018 роки проти попереднього року, найбільша різниця показників простежується на авіаційному, річковому, а також тролейбусному та метрополітенівському транспорті (табл. 3).

Найвищий показник пасажирообороту припадає на наземний транспорт, оскільки він є найбільш мобільним та доступним для усіх верств населення. На другому місці знаходиться авіаційний транспорт, який за останні роки набуває все більшої популярності за рахунок збільшення кількості закордонних поїздок. У порівнянні з 2014 роком показники наземного транспорту попередніх знизилися на 34,4 млрд. пас. км, авіаційного - зросли на 7,8 млрд. пас. км. 


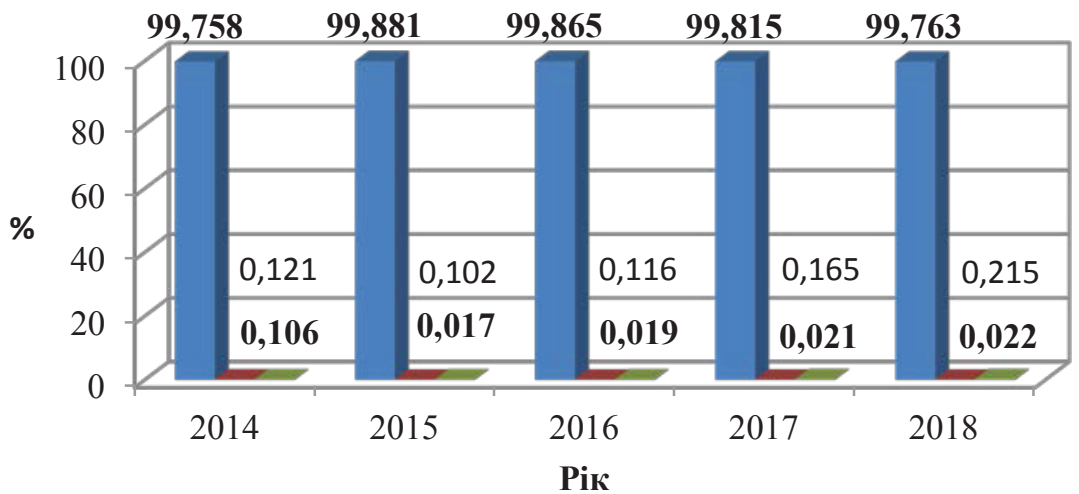

- Наземний

в Водний

- Авіаційний

Рік

Рис. 1. Динаміка обсягів пасажирських перевезень різними видами транспорту за 2014-2018 роки,\%

Таблиця 2

Перевезення пасажирів різними видами транспорту загального користування за 2014-2018 роки, млн. осіб

\begin{tabular}{|c|c|c|c|c|c|c|c|c|c|}
\hline \multirow{2}{*}{ Рік } & \multicolumn{9}{|c|}{ Вид транспорту (млн. осіб) } \\
\hline & Заг. трансп & Залізн. & Автомоб. (автоб.) & Морськ & Річк & Авіац & Трамв & Тролейб & Метро \\
\hline 2014 & 6622,1 & 425 & 3344 & 6 & 2 & 8 & 757 & 1306 & 775 \\
\hline 2015 & 5906,01 & 389 & 2913 & 5 & 1 & 6 & 770 & 1097 & 726 \\
\hline 2016 & 5170,01 & 390 & 2250 & 4 & 1 & 6 & 739 & 1081 & 700 \\
\hline 2017 & 4810,01 & 389 & 2025 & 2 & 1 & 8 & 649 & 1039 & 698 \\
\hline 2018 & 4648,01 & 165 & 2019 & 1 & 1 & 8 & 676 & 1058 & 719 \\
\hline
\end{tabular}

Таблиця 3

Пасажирооборот за різними видами транспорту загального користування у 2014-2018 роках, млрд пас. км

\begin{tabular}{|l|c|c|c|c|c|}
\hline \multirow{2}{*}{\multicolumn{1}{c|}{ Вид транспорту }} & \multicolumn{5}{c|}{ Рік (\% до попереднього року) } \\
\cline { 2 - 6 } & $\mathbf{2 0 1 4}$ & $\mathbf{2 0 1 5}$ & $\mathbf{2 0 1 6}$ & $\mathbf{2 0 1 7}$ & $\mathbf{2 0 1 8}$ \\
\hline Транспорт & 128,3 & 106,3 & 97,0 & 102,2 & 99,4 \\
\hline Наземний & 115,6 & 94,8 & 85,6 & 86,7 & 79 \\
\hline Залізничний & 49,0 & 35,9 & 35,4 & 36,8 & 28,1 \\
\hline Автомобільний (автобуси) & 49,0 & 42,6 & 34,6 & 34,6 & 35,5 \\
\hline Трамвайний & 4,1 & 4,3 & 4,2 & 4,0 & 3,9 \\
\hline Тролейбусний & 7,6 & 6,4 & 6,1 & 5,9 & 6,0 \\
\hline Метрополітенівський & 5,9 & 5,6 & 5,4 & 5,4 & 5,5 \\
\hline Водний & 0,1 & 0 & 0 & 0 & 0 \\
\hline Морський & 0,1 & 0 & 0 & 0 & 0 \\
\hline Річковий & 0 & 0 & 0 & 0 & 0 \\
\hline Авіаційний & 12,6 & 11,6 & 11,4 & 15,5 & 20,4 \\
\hline
\end{tabular}

Пасажирооборот залізничного та автомобільного (автобуси) транспорту протягом п'яти років (20142018 рр.) зазнав несуттєвих змін, хоча показники 2018 року значно нижчі від даних 2014 року, проте у порівнянні з попереднім роком $є$ позитивна динаміка.

3 даних таблиці стає очевидним, що основна частина перевезень пасажирів здійснюється за міським та приміським сполученням, це пов'язано 3 переміщенням економічно активного населення безпосередньо до їхніх робочих місць, а також забезпеченням повсякденних потреб населення у транспортному сполученні. Кількість пасажирських перевезень за усіма видами сполучень за аналізований період скоротилася. За останні два роки відмічається позитивна динаміка збільшення обсягів перевезень авіаційним, трамвайним, тролейбусним та метрополітенівським транспортом. У 2018 році обсяги перевезень зросли відповідно на $0,049 \%, 1,048 \%, 1,157 \%$ та $0,955 \%$.
Нині в Україні нараховується близько 16 тис. суб'єктів господарювання, що мають ліцензію на право здійснювати міжнародні перевезення пасажирів. Маршрутна мережа єднає Україну з 23 іноземними країнами та становить понад 1000 регулярних автобусних маршрутів, які обслуговують близько 270 автомобільних перевізників [3, 20.11.2019].

Загалом станом на 2018 рік на ринку комерційних перевезень пасажирів у приміському та міжміському сполученні в цей час здійснюють підприємницьку діяльність майже 31 тис. перевізників (табл. 4).

Суб'єктами господарювання використовуються різні види транспортних засобів, а саме автобуси, таксі та легкові автомобілі. Кількість транспортних засобів, що використовуються ліцензіатами у 2018 році, наведено у табл. 5 .

Збільшення обсягів пасажирообороту у 2018 році пов'язано $з$ тим, що автобуси та маршрутні таксі є 
Кількість суб'єктів господарювання, що мають ліщензію на право здійснювати перевезення пасажирів, станом на 2018 рік

\begin{tabular}{|l|c|}
\hline \multicolumn{1}{|c|}{ Вид перевезень } & Кількість діючих ліцензій \\
\hline надання послуг з перевезення пасажирів автобусами & 13295 \\
\hline надання послуг з перевезення пасажирів на таксі & 15965 \\
\hline надання послуг з перевезення пасажирів легковими автомобілями на замовлення & 987 \\
\hline надання послуг перевезення пасажирів та небезпечних вантажів & 206 \\
\hline надання послуг перевезення пасажирів та вантажів & 636 \\
\hline Всього & 31089 \\
\hline
\end{tabular}

Кількість транспортних засобів, що використовуються ліцензіатами у 2018 році

Таблиця 5

\begin{tabular}{|c|c|}
\hline Тип транспортного засобу & Кількість транспортних засобів \\
\hline Автобуси & 74527 \\
\hline Таксі & 23484 \\
\hline Легкові & 4490 \\
\hline Всього & 102501 \\
\hline
\end{tabular}

маневренішими, ніж трамваї та тролейбуси, графіки відправлень є більш гнучкими порівняно з трамвайними та тролейбусними відправленнями.

Надійність автомобільних перевезень, як пасажирських, так і вантажних, життєво важлива для економічного зростання і соціального розвитку суспільства [4, с. 2]. Жодна з галузей матеріального виробництва в Україні не здатна функціонувати без транспортного обслуговування. Держава за допомогою нормативно-правових актів здійснює регулювання галузі автомобільного транспорту. Однак велика кількість законодавчих актів, хоча і є обов'язковими для виконання, щодо надійності доставки вантажів та пасажирів, не забезпечує надійної роботи підприємств автомобільного транспорту.

Позначена прогалина в забезпеченні надійності $\epsilon$ однією з причин втрати автомобільним транспортом України важливої конкурентної переваги на світовому ринку автоперевезень, а також всередині країни щодо інших видів транспорту. Тому вдосконалення та розвиток методичного і нормативно-правового забезпечення надійності функціонування транспортних систем доставки автомобільним транспортом є актуальною науково-практичною проблемою, а її вирішення істотно підвищить ефективність та якість роботи транспортної системи України.

У зарубіжних країнах давно склалася практика нормування вимог до надійності автомобільних перевезень, і вона досягла високого рівня. Недотримання норм надійності транспортного обслуговування відображається наявністю збоїв у доставці продукції, безповоротною втратою клієнта, а звідси - зниженням виручки і призупиненням не лише транспортної, але й суміжних робіт.

Реалізація єдиної економічної, інвестиційної, науково-технічної й соціальної політики, підвищення рівня безпеки та якості обслуговування населення автомобільним транспортом сприяє укріпленню позицій ринку пасажирських перевезень.

У сучасних українських реаліях загострюється конкуренція між різними видами транспорту, що сприяє постійному пошуку нових форм і сучасних методів організації пасажирських перевезень для поліпшення умов перевезень (зручності, комфорту), стабілізації вартості проїзду, оптимізації часу доставки пасажирів до місця призначення, підтримки належного технічного стану транспортних засобів і безумовного гарантування безпеки пасажирів і багажу під час пасажирських перевезень.

Негативні тенденції розвитку ринку пасажирських перевезень та прогнозоване зростання потреб у пасажирських перевезеннях вимагають удосконалення транспортної техніки та розроблення більш удосконаленої системи перевезень.

Особливе значення пасажирських перевезень полягає в тому, що ними охоплене майже все населення держави, різні регіони держави за допомогою ринку пасажирських перевезень зв'язуються в одне ціле, таким чином відбувається природна міграція населення.

Висновки. Підвищення ефективності функціонування транспортного комплексу України можливе за рахунок низки урядових заходів, таких як:

- удосконалення комплексу державного регулювання системи перевезень пасажирів (екологічні стандарти, норми безпеки та охорона праці, ліцензування діяльності, контроль щодо транспортних тарифів);

- реструктуризація системи управління пасажирським комплексом для орієнтації на пасажирів;

- удосконалення правової бази пасажирських перевезень;

- вилучення та заміна застарілих та фізично зношених транспортних засобів;

- впровадження економічно обгрунтованих тарифів на перевезення;

- раціоналізація та удосконалення графіку руху транспорту.

Стабільне майбутнє міських пасажирських автомобільних перевезень може бути забезпечено такими шляхами, як:

- впровадження системи регульованої конкуренції як найбільш перспективної. При цьому, мабуть, неминуче зменшення ролі держсектора, незважаючи на його певні переваги в якості послуг, що надаються. 
- визнання неминучості державного фінансування, причому воно повинне відігравати ключову роль разом з реалізацією виняткових прав.

- природне укрупнення підприємств, що здійснюють міські пасажирські автомобільні перевезення як державного, так і приватного сектору, бо дрібні підприємства не мають достатніх обігових коштів для розвитку цього бізнесу.

- широке застосування делегованого менеджменту, коли держава делегує свої повноваження 3 управління пасажирськими перевезеннями. Це дає можливість громадським органам адміністрації міста делегувати приватному операторові організацію пасажирських перевезень за контрактом на певний термін, отриманий за результатами проведеного конкурсу.

У відповідних планах розвитку транспортного забезпечення громадян мають бути передбачені технології для забезпечення безпеки руху, такі як впровадження систем «інтелектуального» управління швидкістю автомобіля, вдосконалення систем активної і пасивної безпеки автомобілів.

\section{Список літератури:}

1. Марунич В.С., Шморгун Л.Г. та ін. Організація та управління пасажирськими перевезеннями : підручник. Київ : Міленіум, 2017. 528 с.

2. Носов А.Л. Транспортная логистика: методика обследования транспортных потоков и подвижности населения города : РИСК: Ресурсы, информация, снабжение, конкуренция. 2015. № 2. С. 36-42.

3. Головне управління статистики м. Києва URL: http:// www.ukrstat.gov.ua/ (дата звернення 20.11.2019).

4. Зайцева М.M. Эффективность и надежность работы персонала предприятий автомобильного транспорта. Инженерный вестник Дона. 2015. № 3 [електронный ресурс] URL: http://ivdon.ru/ru/magazine/archive/n3y2015/3188 (дата звернення 20.11.2019).

\section{References:}

1. Marunych V.S., Shmorghun L.Gh. ta in. (2017) Orghanizacija ta upravlinnja pasazhyrsjkymy perevezennjamy : pidruchnyk [Organization and management of passenger transportation : a textbook]. Kyjiv : Milenium. (in Ukrainian)

2. Nosov A.L. (2015) Transportnaja logistika: metodica obsledovanija transportnich potokov I podviznosti naselenija goroda [Transport logistics: a technique for surveying traffic flows and the mobility of the city population]. RISK: resursi, informacija, snabzenije, konkurencija, no 2, pp. 36-42.

3. Golovne upravlinnja statistiki Kijeva [Main Department of Statistics of Kyiv]. Available at: http:// www.ukrstat.gov. ua/ (accessed 20.11.2019).

4. Zaiceva M.M. (2015) Effektivnost I nadeznost raboti personzlz predprijatij avtomobilnogo transporta [Efficiency and reliability of the staff of automobile transport enterprises]. Inzenernij vesnik Dona, no. 3. Available at: http://ivdon.ru/ru/ magazine/archive/n3y2015/3188 (accessed 20.11.2019).

\section{ПРОБЛЕМЫ И ПЕРСПЕКТИВЫ РАЗВИТИЯ РЫНКА ПАССАЖИРСКИХ АВТОМОБИЛЬНЫХ ПЕРЕВОЗОК В УКРАИНЕ}

В статье рассмотрен рынок пассажирских перевозок в Украине. Определены экономические, правовые, технико-технологические и социальнье проблемь развития автомобильного транспорта. Сформировань проблемнье позиции по качеству обслужсивания пассажиров. Наибольшая доля перевозок пассажсиров приходится на наземный транспорт, это больше 99\%, на авиационный транспорт приходится более 1\%, водным транспортом осушествляется наименьшее количество пассажирских перевозок. Пассажсирооборот железнодорожного и автомобильного (автобусы) транспорта в течение пяти лет (2014-2018 г2.) имел несущественнье изменения. Хотя показатели 2018 г. значительно ниже относительно данных 2014 г., однако по сравнению с предыдущим годом существует положительная динамика. Указан перечень правительственных мер по повышению эффективности функционирования транспортного комплекса Украины.

Ключевые слова: пассажирские перевозки, транспортная отрасль, автомобильный транспорт, автомобилизация, пассажирооборот.

\section{PROBLEMS AND PROSPECTS FOR THE PASSENGER CAR TRANSPORTATION MARKET DEVELOPMENT IN UKRAINE}

The article discusses the passenger transportation market in Ukraine. Effective work of the transport industry influences the well-being of the population. Reliability of road transport both passenger and freight is vital for economic growth and social development of society. None of the branches of material production in Ukraine is able to function 
without transport services. It was determined that for the efficient management of passenger traffic it is necessary to introduce new techniques and technologies. The main problems in the development of motor transport are grouped into four categories. Incompletely resolved issues regarding the quality of passenger service were identified. The dynamics of the volume of passenger traffic by different modes of transport over the past five years was examined. The number of valid licenses by mode of transportation is analyzed. Improvement and development of methodological and regulatory legal support for the reliability of the functioning of transport delivery systems by road is an urgent scientific and practical problem, and its solution will significantly improve the efficiency and quality of the automobile transport system of Ukraine. The implementation of a single economic, investment, scientific, technical and social policy, improving the level of safety and quality of service to the population by road helps to strengthen the position of the market of passenger transportation. In today's Ukrainian realities competition between different modes of transport is aggravated, which facilitates a constant search for new forms and modern methods of organization of passenger transportation for improvement of conditions of transportation (convenience, comfort), stabilization of the cost of travel, optimization of the time of delivery of passengers to the destination, maintenance of proper technical condition. Means and unconditional guarantee of safety of passengers and luggage during passenger transportation. State measures aimed at increasing the efficiency of the functioning of the transport complex of Ukraine are considered.

Key words: passenger transportation, transport industry, road transport, automation, passenger traffic. 